\title{
Article/Artigo
}

\section{Candida spp. isolated from inpatients, the environment, and health practitioners in the Pediatric Unit at the Universitary Hospital of the Jundiaí Medical College, State of São Paulo, Brazil}

\author{
Candida spp. isoladas de pacientes internados, profissionais da saúde e de ambiente na Unidade de \\ Pediatria do Hospital Universitário da Faculdade de Medicina de Jundiaí, Estado de São Paulo, Brasil \\ Lucas Ruiz Storti ${ }^{1}$, Giuliano Pasquale ${ }^{1}$, Rogério Scomparim ${ }^{1}$, Ana Lúcia Galastrii ${ }^{2}$, Flávio Alterthum ${ }^{2,3}$, \\ Walderez Gambale ${ }^{2,3}$ and Claudete Rodrigues Paula ${ }^{3}$
}

\section{ABSTRACT}

Introduction: This study aimed to isolate and identify Candida spp. from the environment, health practitioners, and patients with the presumptive diagnosis of candidiasis in the Pediatric Unit at the Universitary Hospital of the Jundiaí Medical College, to verify the production of enzymes regarded as virulence factors, and to determine how susceptible the isolated samples from patients with candidiasis are to antifungal agents. Methods: Between March and November of 2008 a total of 283 samples were taken randomly from the environment and from the hands of health staff, and samples of all the suspected cases of Candida spp. hospital-acquired infection were collected and selected by the Infection Control Committee. The material was processed and the yeast genus Candida was isolated and identified by physiological, microscopic, and macroscopic attributes. Results: The incidence of Candida spp. in the environment and employees was $19.2 \%$. The most frequent species were C. parapsilosis and C. tropicalis among the workers, C. guilliermondii and C. tropicalis in the air, C. lusitanae on the contact surfaces, and C. tropicalis and $C$. guilliermondii in the climate control equipment. The college hospital had 320 admissions, of which 13 (4\%) presented Candida spp. infections; three of them died, two being victims of a C. tropicalis infection and the remaining one of C. albicans. All the Candida spp. in the isolates evidenced sensitivity to amphotericin B, nystatin, and fluconazole. Conclusions: The increase in the rate of hospital-acquired infections caused by Candida spp. indicates the need to take larger measures regarding recurrent control of the environment.

Keywords: Candidemia. Neonatal Intensive Care Unit. Nosocomial infection. Pediatric Intensive Care Unit.

\section{RESUMO}

Introdução: Isolar e identificar Candida spp. do ambiente, dos profissionais de saúde e de pacientes com diagnóstico presuntivo de candidíase, em Unidade de Pediatria do Hospital Universitário da Faculdade de Medicina de Jundiaí, verificar a produção de enzimas consideradas fatores de virulência e identificar a resistência das cepas isoladas dos pacientes aos antifúngicos. Métodos: Foram feitas 283 coletas no período entre março e novembro de 2008 de forma randomizada do ambiente, das mãos de profissionais de saúde e de todos os pacientes com casos suspeitos de infecção hospitalar por Candida spp., triados pelo Comitê de Infecção Hospitalar. Todo o material coletado foi processado e as leveduras do gênero Candida foram isoladas e identificadas pelas características macroscópicas, microscópicas e fisiológicas. Resultados: A incidência de Candida spp. no meio-ambiente e funcionários foi de 19,2\%. Destes, as espécies mais frequentes entre os funcionários foram C. parapsilosis e C. tropicalis; no ar ambiente, C. guilliermondii e C. tropicalis; nas superfícies dos ambientes, C. lusitanae e nos sistemas de climatização, C. tropicalis e C. guilliermondii. No período de estudo, foram feitas 320 internações, e 13 (4\%) apresentaram infecção hospitalar por Candida spp, sendo que 3 pacientes foram a óbito, dois apresentando infecção por $C$. tropicalis e um por C. albicans. Todas as espécies de Candida spp. isoladas dos pacientes foram sensíveis à anfotericina $\mathrm{B}$, nistatina e fluconazol. Conclusões: Verificamos um aumento crescente de infecções hospitalares por Candida não albicans, o que sugere a necessidade de maiores precauções em relação a um controle ambiental destas espécies. Palavras-chaves: Candidemia. Unidade Neonatal de Terapia Intensiva. Infecção hospitalar. Unidade Pediátrica de Terapia Itensiva.

1. Curso de Medicina, Faculdade de Medicina de Jundiaí, Jundiaí, SP. 2. Departamento de Morfologia e Patologia Geral, Faculdade de Medicina de Jundiaí, Jundiaí, SP. 3. Departamento de Microbiologia, Instituto de Ciências Biomédicas, Universidade de São Paulo, São Paulo, SP.

Address to: Dr. Lucas Ruiz Storti. Av. Nove de Julho 1450/161, Parque do Colégio, 13209-011 Jundiaí, SP, Brasil.

Phone: 5511 4521-7918

e-mail: 1.storti@gmail.com

Received in $22 / 04 / 2010$

Accepted in 16/09/2010

\section{INTRODUCTION}

An increasing number of fungal infections have been detected on a global level. This raises an important matter of public health ${ }^{1}$, as it makes hospital stays longer ${ }^{2}$ and stands as relevant cause of morbidity and mortality among patients ${ }^{2-9}$. The mortality rate associated with Candidemia in the United States has recently been estimated at $49 \%^{1}$, a rate that may reach $75 \%$ in neonatal intensive care units (NICU) ${ }^{5}$, while the expenses attributed to an episode of invasive candidiasis are estimated at approximately $\$ 28,000$ and $\$ 48,000$ for pediatric and adult patients, respectively ${ }^{1}$.

In the last 20 years, the whole world has seen a meaningful increase in infections caused by Candida spp., especially in intensive care units (ICU) ${ }^{2,10}$; the main risk factors have been established, namely, low weight, preterm birth, immunological deficiency, congenital disorders, use of third-generation cephalosporins, invasive routine procedures, use of vascular catheters, and a long period of hospital ingression ${ }^{3-5,8}$. Candida albicans is the species that mainly causes nosocomial infections, although some non-albicans species are also reported as causal agents ${ }^{2,3,9}$. Among the most recurrent species of Candida non-albicans, C. tropicalis, C. parapsilosis, C. krusei, and C. glabrata find more prominence. In the 1980s, C. albicans used to be the most frequent pathogen of nosocomial bloodstream infections, and since the 1990s its yeasts have become the third main cause of hospital-acquired infections ${ }^{8,10}$.

Nosocomial fungal infections may have their origin in endogenous strains (introduced into the hospital by the patients themselves) or in exogenous sources, transmitted to patients via contaminated infusions, biomedical devices, or even by the hands of the hospital staff members ${ }^{1,3,11,12}$. Besides, it has been noticed that constant contact with patients in a hospital environment facilitates cross-contamination inside the ICU ${ }^{1,2,3,8,11,12}$. Considering the relevance of Candida spp. as infectious agents in dissemination, 
the diversity of such species, and the occurrence of strains that can resist the main antifungal agents, the aims of this study were to isolate and identify the Candida spp. in the environment, health professionals, and patients with the presumptive diagnosis of candidiasis in the pediatric unit at the hospital in the Jundiaí Medical College; to verify the production of enzymes regarded as virulence factors (phospholipase and proteinase); and to identify how susceptible the isolated samples from patients with candidiasis are to antifungal agents.

\section{METHODS}

This research was developed at the hospital associated with the Medical College of Jundiaí and integrated into the Single Health System (SUS, in Portuguese) in the City of Jundiaí, State of São Paulo, Brazil. The hospital stands on the intermediate level of care and allocates 62 beds, consisting of 13 in the NICU, 19 in the semiNICU and late admission wards, 6 in the pediatric intensive care unit (PICU), and 24 pediatric beds, which earns it the title of third-level medium-sized hospital. The hospital staff comprises 30 physicians and 40 nurses at the NICU and semi-NICU, 14 physicians on duty, 34 nurses at the pediatric ward and PICU, and 10 resident physicians.

From March to November 2008, monthly random samples were collected from the hospital air and staff in the following manner: 108 samples from the hospital staff (doctors, nurses, and healthcare assistants), 72 samples from room air (pediatric ward rooms, toy room, operating room, NICU, and PICU), 63 from contact surfaces in the toy room and from the NICU and PICU (door handles, light switches, counters, chairs, toys, remote controls), and 27 from the water-collection trays in the climate control equipment.

Air samples were collected through the technique of Sabouraud dextrose agar plate preparation (DIFCO ${ }^{\mathrm{rm}}$ ) and CHROMagar Candida (Microbiology ${ }^{\mathrm{Tx}}$ ). The samples were exposed to the environment for $30 \mathrm{~min}$ and kept in a stove at $37^{\circ} \mathrm{C}$ for $96 \mathrm{~h}^{13}$.

The samples from contact surfaces were collected by sterile swab suspension in $1 \mathrm{ml}$ of saline solution rubbed on a $5 \mathrm{~cm}^{2}$ area of walls, toys, and trays in the climate control equipment. The same method was employed in collecting the samples from the hospital staff, by rubbing the sterile swab on the hands and nails. The collected material was immediately processed in the lab through the culture of Sabouraud dextrose agar plates and CHROMagar and was maintained in a stove at $37^{\circ} \mathrm{C}$ for $96 \mathrm{~h}$.

All the suspected cases of hospital-acquired invasive candidiasis were selected by the Infection Control Committee during the period of this study. Samples were collected and immediately sent to the laboratory for identification.

The isolated yeasts were identified by physiological, microscopic, and macroscopic attributes, following the methodology supported by Kurtzman and Fell ${ }^{14}$.

The proteinase secretion of the isolated Candida species was tested through the procedure described by Ruchel et al. ${ }^{15}$, and the phospholipase activity was tested according to Price et al. ${ }^{16}$; the activity rate of those enzymes $(\mathrm{Pz})$ was achieved by following Price et al., and the samples considered as positive were those revealing $\mathrm{Pz}<1.0^{16}$.

The Candida spp. isolates from patients were submitted to susceptibility testing via disk diffusion antibiotic sensitivity testing.
The isolates had been previously grown in Sabouraud dextrose agar $\left(\mathrm{DIFCO}^{\mathrm{Tx}}\right.$ ) at $37^{\circ} \mathrm{C}$ for $24 \mathrm{~h}$; after this culture, the isolates experienced suspension in sterile saline solution to $0.5 \mathrm{McF}$ arland scale. With a sterile swab, the inoculum was spread on Muller Hinton agar $\left(\mathrm{DIFCO}^{\mathrm{mx}}\right)$, supplemented with $2 \%$ of glucose and $0.5 \mathrm{ug} / \mathrm{ml}$ of methylene blue. Disks of amphotericin B, fluconazole, econazole, itraconazole, 5-fluorocytosine, and ketoconazole were also employed. The plates were incubated in a stove at $37^{\circ} \mathrm{C}$ for $24 \mathrm{~h}$. The results were interpreted as sensitive $(S)$, intermediate (I), or resistant (R), following the instructions given by the manufacturer $\left(\mathrm{CECON}^{\mathrm{Tm}}\right)$.

The associations were statistically evaluated by Fisher's exact test (significance level 5\%) and SAS software version 9.1.3.

\section{Ethical considerations}

The protocol was conducted following the ethical principles established in the Declaration of Helsinki proposed by the World Medical Association (Declaration of Helsinki, 1964, 1975, 1983, $1989,1996,2000)$. The project was submitted for approval by the Ethics Committee in Research of the Jundiaí Medical College. All participants were informed about the project and degree of involvement in it, and were asked to sign the Instrument of Consent (Ministry of Health/National Health Foundation, 1996), consisting of clarification regarding the following aspects: I) justification, objectives, and procedures used; II) discomfort, potential risks, and expected benefits; III) a follow-up and assistance and their respective officers; IV) the freedom to refuse to participate or withdraw their consent at any stage of the research without penalty or loss; and vi) assurance of confidentiality regarding the data collected.

\section{RESULTS}

During the study, a total of 270 sample involving both the environment and its workers were collected, and Candida spp. were isolated in 52 (19.2\%) of these samples. The species C. albicans was isolated only once, from a healthcare assistant. Considering all the other places, only Candida non-albicans species were isolated. The largest isolation rate happened in the system of climate control (33.3\%), followed by the contact surfaces $(23.8 \%)$, staff $(15.7 \%)$, and room air (15.3\%) (Table 1).

Considering the members of the hospital staff, the largest isolation rate occurred among the healthcare assistants (20.4\%), and the single room-air isolation was from the toys room. In relation to the contact surfaces analyzed and the climate control system, the largest rates occurred at the PICU at $44.4 \%$ and $66.7 \%$, respectively. No isolation was obtained from the climate control equipment in the operating room (Table $\mathbf{1}$ ).

In view of the isolated species, the most frequent was C. tropicalis (27.4\%), followed by C. guilliermondii (23.5\%), C. parapsilosis (19,6\%), C. lusitanae (17.6\%), and C. krusei (11.8\%) (Table 2).

The most frequent species were $C$. parapsilosis and $C$. tropicalis among the hospital employees, C. guilliermondii and C. tropicalis in the room air, C. lusitanae on the contact surfaces, and C. tropicalis and C. guilliermondii in the climate control devices (Table 2).

During this research, the hospital attended to 320 ingressions, of which 13 (4\%) revealed hospital-acquired infections by Candida spp. (invasive candidiasis); 5 of these patients were staying at the NICU and 8 at the PICU. 
TABLE 1 - Frequency of Candida albicans and Candida non-albicans in 270 samples from The environment and staff at the Universitary Hospital of the Jundiaí Medical College, State of São Paulo, Brazil, from March to November 2008.

\begin{tabular}{lcccc}
\hline & $\begin{array}{r}\text { Collected } \\
\text { samples (n) }\end{array}$ & $\begin{array}{c}\text { Candida } \\
\text { albicans }\end{array}$ & $\begin{array}{c}\text { Candida } \\
\text { non-albicans }\end{array}$ & $\begin{array}{c}\text { Frequency } \\
(\%)\end{array}$ \\
\hline Workers & 27 & 0 & 4 & 14.8 \\
$\begin{array}{l}\text { physicians } \\
\text { nurses }\end{array}$ & 27 & 0 & 2 & 7.4 \\
healthcare assistants & 54 & 1 & 10 & 20.4 \\
\hline Total & $\mathbf{1 0 8}$ & $\mathbf{1}$ & $\mathbf{1 6}$ & $\mathbf{1 5 . 7}$ \\
\hline Room air & 27 & 0 & 5 & 18.5 \\
rooms & 9 & 0 & 0 & 0.0 \\
toy room & 36 & 0 & 6 & 16.7 \\
ICUs and operating room & $\mathbf{7 2}$ & $\mathbf{0}$ & $\mathbf{1 1}$ & $\mathbf{1 5 . 3}$ \\
\hline Total & & & & \\
\hline Contact surface & & & & \\
\hline
\end{tabular}

\begin{tabular}{lrrrr}
\hline $\begin{array}{l}\text { Contact surface } \\
\text { toy room }\end{array}$ & 36 & 0 & 9 & 25.0 \\
NICU & 18 & 0 & 2 & 11.1 \\
PICU & 9 & 0 & 4 & 44.4 \\
\hline Total & $\mathbf{6 3}$ & $\mathbf{0}$ & $\mathbf{1 5}$ & $\mathbf{2 3 . 8}$
\end{tabular}

\begin{tabular}{lrrrr}
\hline Climate control system & & & & \\
PICU & 9 & 0 & 6 & 66.7 \\
NICU & 9 & 0 & 3 & 33.3 \\
operating room & 9 & 0 & 0 & 0.0 \\
\hline Total & $\mathbf{2 7}$ & $\mathbf{0}$ & $\mathbf{9}$ & $\mathbf{3 3 . 3}$ \\
\hline Sum total & $\mathbf{2 7 0}$ & $\mathbf{1}$ & $\mathbf{5 1}$ & $\mathbf{1 9 . 3}$
\end{tabular}

ICUs: intensive care units; PICU: pediatric intensive care unit; NICU: neonatal intensive care unit.

Seven of the 13 cases presented C. albicans infection; 3 were C. tropicalis, 1 C. parapsilosis, 1 C. krusei, and 1 C. guilliermondii (Table 3). The isolates of Candida spp. from the infections were obtained through blood culture ( 9 of the cases) and urine culture (4 of the cases). Three patients died. Two of them were inpatients at the NICU, with one infected by C. albicans and the other by C. tropicalis; the third patient who died was at the PICU and presented an infection by $C$. tropicalis.

All the Candida spp. isolated from the patients were sensitive to amphotericin B, nystatin, and fluconazole. In relation to econazole and itraconazole, some samples presented intermediate susceptibility, but only one sample of $C$. albicans was resistant to econazole (Table 4).

To calculate the enzyme activity of proteinase and phospholipase, the $\mathrm{Pz}$ value was applied according to Price et al., with isolates with $\mathrm{Pz}<1.0$ considered as positive. Considering the $8 \mathrm{C}$. albicans isolates, $87.5 \%$ were regarded as positive for phospholipase activity, whereas only $8.8 \%$ of the Candida non-albicans presented positivity.
TABLE 2 - Incidence of Candida non-albicans species in 51 isolates from the environment and staff at the Universitary Hospital of the Jundiaí Medical College, State of São Paulo, Brazil, from March to November 2008.

\begin{tabular}{llllll}
\hline & \multicolumn{5}{c}{ Candida } \\
\cline { 2 - 6 } & tropicalis & parapsilosis & krusei & lusitaneae & guilliermondii \\
\hline Workers & 1 & 1 & 2 & 0 & 0 \\
physicians & 1 & 1 & 0 & 0 & 0 \\
nurses & 3 & 4 & 1 & 0 & 2 \\
healthcare assistants & $\mathbf{5}$ & $\mathbf{6}$ & $\mathbf{3}$ & $\mathbf{0}$ & $\mathbf{2}$ \\
\hline Total & & & & & \\
\hline Room air & 3 & 1 & 0 & 1 & 0 \\
rooms & 0 & 0 & 0 & 0 & 0 \\
toy room & 1 & 0 & 0 & 0 & 5 \\
ICUs and operating room & 1 & $\mathbf{1}$ & $\mathbf{0}$ & $\mathbf{1}$ & $\mathbf{5}$ \\
\hline Total & $\mathbf{4}$ & &
\end{tabular}

\section{Contact surface}

\begin{tabular}{llllll} 
toy room & 0 & 1 & 2 & 6 & 0 \\
NICU & 0 & 1 & 0 & 0 & 1 \\
PICU & 1 & 1 & 1 & 1 & 0 \\
\hline Total & $\mathbf{1}$ & 3 & 3 & 7 & 1
\end{tabular}

\begin{tabular}{lrrrrr}
\hline Climate control system & & & & & \\
PICU & 3 & 0 & 0 & 0 & 3 \\
NICU & 1 & 0 & 0 & 1 & 1 \\
operating room & 0 & 0 & 0 & 0 & 0 \\
\hline Total & $\mathbf{4}$ & $\mathbf{0}$ & $\mathbf{0}$ & $\mathbf{1}$ & $\mathbf{4}$ \\
\hline Sum Total & $\mathbf{1 4}$ & $\mathbf{1 0}$ & $\mathbf{6}$ & $\mathbf{9}$ & $\mathbf{1 2}$
\end{tabular}

ICUs: intensive care units; PICU: pediatric intensive care unit; NICU: neonatal intensive care unit.

In the light of the proteinase, only $12.5 \%$ of C. albicans and $21.1 \%$ of Candida non-albicans were positive, presenting no significant differences among the isolates from the range of groups. In relation to phospholipase activity in the patients' isolates, a relevant difference was observed between the C. albicans and Candida non-albicans isolates (Table 5).

TABLE 3 - Hospital-acquired infection by Candida spp. detected in 13 patients in the NICU and PICU at the Hospital of the Jundiaí Medical College, State of São Paulo, Brazil, from March to November 2008.

\begin{tabular}{lccc}
\hline \multirow{2}{*}{ Species } & \multicolumn{2}{c}{ Cases } \\
\cline { 2 - 3 } & $\mathbf{n}$ & $\%$ \\
\hline Candida albicans & 7 & 53.8 \\
\hline Candida tropicalis & 3 & 23.1 \\
\hline Candida parapsilosis & 1 & 7.7 \\
\hline Candida krusei & 1 & 7.7 \\
\hline Candida guilliermondii & 1 & 7.7 \\
\hline
\end{tabular}

PICU: pediatric intensive care unit; NICU: neonatal intensive care unit.

TABLE 4 - Antifungal susceptibility testing of Candida spp. isolates from 13 patients in the NICU and PICU at the hospital of the Jundiaí Medical College, State of São Paulo, Brazil, from March to November 2008.

\begin{tabular}{|c|c|c|c|c|c|c|c|c|c|c|c|}
\hline \multirow[b]{2}{*}{ Species of Candida } & \multirow{2}{*}{$\frac{\text { Samples }}{\mathrm{n}}$} & \multirow{2}{*}{$\frac{\text { Amphotericin B }}{S}$} & \multicolumn{3}{|c|}{ Econazole } & \multirow{2}{*}{$\frac{\text { Nystatin }}{S}$} & \multicolumn{2}{|c|}{ Ketoconazole } & \multicolumn{2}{|c|}{ Itraconazole } & \multirow{2}{*}{$\frac{\text { Fluconazole }}{S}$} \\
\hline & & & $\mathbf{S}$ & I & $\mathbf{R}$ & & $\mathbf{S}$ & I & $\mathbf{S}$ & $\mathbf{I}$ & \\
\hline albicans & 7 & 7 & 5 & 1 & 1 & 7 & 3 & 4 & 7 & 0 & 7 \\
\hline tropicalis & 3 & 3 & 2 & 1 & 0 & 3 & 3 & 0 & 2 & 1 & 3 \\
\hline parapsilosis & 1 & 1 & 1 & 0 & 0 & 1 & 1 & 0 & 1 & 0 & 1 \\
\hline krusei & 1 & 1 & 1 & 0 & 0 & 1 & 1 & 0 & 0 & 1 & 1 \\
\hline guillermondii & 1 & 1 & 1 & 0 & 0 & 1 & 1 & 0 & 1 & 0 & 1 \\
\hline
\end{tabular}

PICU: pediatric intensive care unit; NICU: neonatal intensive care unit; S: sensitive; I: intermediate; R: resistant. 
TABLE 5 - Positivity of proteinase and phospholipase activities (Price et al., 1982) in Candida albicans and Candida non-albicans isolates from patients and environment at the Hospital of the Jundiaí Medical College, State of São Paulo, Brazil SP, from March to November 2008.

\begin{tabular}{lccc}
\hline & $\begin{array}{c}\text { Number of } \\
\text { patients }\end{array}$ & $\begin{array}{c}\text { Isolations } \\
\text { environment }\end{array}$ & Total \\
\hline Candida albicans & 7 & 1 & 8 \\
\hline Proteinase activity $(\mathrm{n} / \%)$ & $1 / 14.3$ & $0 / 0.0$ & $1 / 12.5$ \\
\hline Phospholipase activity (n/\%) & $6 / 85.7^{*}$ & $1 / 100.0$ & $7 / 87.5$ \\
\hline Candida non-albicans/number of isolations & 6 & 51 & 57 \\
\hline Proteinase activity $(\mathrm{n} / \%)$ & $1 / 16.7$ & $11 / 21.5$ & $12 / 21.1$ \\
\hline Phospholipase activity $(\mathrm{n} / \%)$ & $1 / 16.7^{*}$ & $4 / 7.8$ & $5 / 8.8$ \\
\hline
\end{tabular}

*statistically significant difference $\mathrm{p}>0.05$.

\section{DISCUSSION}

Nosocomial infections caused by Candida spp. currently represent a serious matter for the public health, since the rates of incidence and mortality associated with these infections have revealed a considerable increase in third-level hospitals during the last decades ${ }^{17-19}$. Species of the genus Candida have been the most frequently isolated agents, which correspond to approximately $80 \%$ of the hospital-acquired fungal infections that cause death to $12 \%$ to $60 \%$ of the patients who develop candidemia ${ }^{19-21}$.

The occurrence of nosocomial infections by invasive candidiasis at the Universitary Hospital of the Jundiaí Medical College during the period covered by this research was of $4 \%$ above the average described by national and international references, which report an occurrence rate of 1.49 to 6.6 cases in 1,000 hospital admissions ${ }^{22-26}$.

The hospital sector where cases of candidemia are most commonly found is the ICU, for besides being the place where patients find themselves more impaired, it also completes a routine of invasive procedures, probes, and long-term catheters ${ }^{19,27-29}$. All the candidemia cases in this study were observed in patients in ICUs, a point that is also discussed by other studies that recognize the ICU as a place of utmost susceptibility to the incidence of such infection ${ }^{30-33}$.

The absolute mortality rate due to candidemia was $23.1 \%$, a result that is also consonant with the data provided by the bibliographic references ${ }^{18-20}$. Two of the patients who died were immunosuppressive newborns; they were in the NICU, and they acquired sepsis. The third patient who died was a 7-year-old child who had heart co-morbidity and was settled in the PICU. The two Candida species responsible for these mortality cases were C. albicans and C. tropicalis.

Candida albicans was the species most frequently found among patients $(53.8 \%)$, corroborating what other studies have been demonstrating in different anatomical sites ${ }^{19,30,31,34,35}$.

On the other hand, many researches have exposed the last decades' increase of infections as caused by other species of Candida $a^{2,3,18,19,30,31}$. This point was also verified in our study, which showed the relevance of identifying different Candida spp., aimed at gaining better epidemiological knowledge about the disease and its usual resistance to therapy, typical of the Candida non-albicans species that not only make the treatment difficult and expensive, but also provide an inaccurate prognostic ${ }^{36}$.

Among the Candida non-albicans species, the most recurring one was C. tropicalis (23.1\%), which along with C. albicans accounts for $76.9 \%$ of the candidemia cases and stands as the second most common pathogen, a fact that was already noticed in another work ${ }^{37}$. Fifty percent to $60 \%$ of the patients who present this species are expected to develop systemic infections ${ }^{38}$. Other studies point to C. parapsilosis as the most prevalent species among the Candida non-albicans ${ }^{1-4,18,24,34,35,39}$. In pediatric or neonatal units, C. parapsilosis has been marked as the second most common agent in patients with candidemia, a fact that is linked to the exogenous contamination because of the patients' manipulation by the hospital staff, the patients' exposure to invasive procedures in the ICU, prematurity, immunosuppression, and long-course antibiotic therapy $34,35,39-41$. Results from many other works have evidenced C. tropicalis or C. parapsilosis as the main Candida non-albicans agent involved in the different types of candidemia around us ${ }^{38,42-47}$, which is different from what has been observed in Europe and North America, where C. glabrata has been detected as the second most recurrent pathogen after $C$. albicans ${ }^{43,44,47-49}$. This species was not isolated in our research.

Displaying an inferior occurrence that represents $23.1 \%$ of the remaining candidemia cases, C. parapsilosis (7.7\%), C. krusei (7.7\%), and C. guilliermondii (7.7\%) were also identified in this study.

In relation to the samples isolated from the room air and the staff, the Candida non-albicans species were predominant and represented by C. tropicalis, C. parapsilosis, C. guilliermondii, C. lusitaneae, and C. krusei, a fact that confirms what other studies have demonstrated ${ }^{2,24,50,51}$. With reference to health practitioners, some researches inform that $C$. albicans is the most commonly isolated species from the hands of the healthcare staff $^{51,52}$, while some authors have identified C. tropicalis and C. parapsilosis as dominant species $2,12,24,50,51$. In this work, C. albicans was isolated only once from the hand of a healthcare assistant; it was never isolated from the room air.

The incidence of Candida spp. among the workers was $15.7 \%$, an average that is below the result previously verified by other studies $^{52,53}$. However, except for C. lusitaneae, which was not isolated from any patient in this research, the remaining isolates of Candida non-albicans from the environment and the hands of the hospital staff members were also isolated from the patients. This fact might indicate an exogenous transmission via direct contact, which makes necessary a number of comparative molecular studies to confirm this hypothesis. Although most candidemia cases occur because of a pre-existent colonization in the patient (by the same species of yeast that causes the infection), hematopoietic infections of difficult control may also be acquired through manipulation and direct contact made by the hands of healthcare professionals ${ }^{54-58}$.

There was a correlation between the incidence of $C$. tropicalis and C. guilliermondii, the room air, and the trays in the climate control equipment: all the Candida spp. samples from these places were Candida non-albicans, with a positivity rate of $15.3 \%$ in the room air and $33.3 \%$ in the climate control system. In view of the results, it is not possible to state that the same species detected in the climate control system were responsible for contamination and migration to the room air, since the operating room did not have Candida spp. positive in its climate control equipment, although C. guilliermondii actually had a positive detection in the room air. Nevertheless, both the climate control system and the room air in the PICU presented C. guilliermondii positivity, which might imply a yeast migration through the climate control system. 
Considering the total samples collected from the furniture surface, $23.8 \%$ were positive for Candida spp., all of them being Candida non-albicans, with a prevalence of $C$. lusitaneae, which differs from a similar study that found a dominance of C. guilliermondii on the surface of the hospital furniture ${ }^{51}$.

The Candida non-albicans isolates verified in this range of sectors, plus the growing increase in hospital-acquired infections caused by these species observed in recent years, suggest the importance of being attentive to frequent control of environment. A number of works have implied that the proteinase and phospholipase enzymes might be virulence factors of Candida spp $^{59-62}$.

In relation to proteinase, there was no significant difference in the production of this enzyme between C. albicans and the Candida nonalbicans isolated from patients, corresponding to $14.3 \%$ and $16.7 \%$ of the samples, respectively. It is important to note that $21.5 \%$ of the Candida non-albicans samples isolated from the environment showed proteinase activity. Other studies demonstrate a larger incidence of proteinase production by Candida non-albicans species ${ }^{25,29,59,60}$.

On the other hand, $85.7 \%$ of the C. albicans samples isolated from patients were positive for phospholipase activity, whereas only $16.7 \%$ of the Candida non-albicans revealed phospholipase positivity, suggesting that this enzyme and $C$. albicans might be associated but are independent of virulence, as confirmed by other works that attest to the predominant production of phospholipase among C. albicans isolates from both healthy individuals and pathogenic cases, proving that phospholipase synthesis is not restricted to pathogenic samples $\mathrm{s}^{24,28,36,46,52,58}$. Such fact also implies that phospholipase is not a determinant factor of the disease settlement, once the host immunity, the endogenous presence of $C$. albicans, and the effectiveness of the pathogenicity in the samples are also considered.

Other studies demonstrate that pathogenic samples produce more proteinase than phospholipase $\mathrm{e}^{47,53,59,60,63}$. However, this is a controversial statement, and this discussion concerning enzyme activity as a virulence factor of Candida spp. remains unresolved.

Analysis of the antifungal susceptibility testing of Candida spp. isolates from pediatric patients showed all the samples to be in vitro sensitive to the main treatment drugs used in our hospital, fluconazole and amphotericin B. Nevertheless, there are several divergences concerning the resistance to antifungal therapies, especially among the Candida non-albicans species, which have presented resistance to the treatment elected in different parts of the world ${ }^{2,4,8,9,64,65}$.

The treatment accomplished in our work was satisfactory and is according to the reality in most public hospitals in Brazil, where the first-choice drug for candidemia is fluconazole ${ }^{22}$. However, there is a new therapeutic class of antifungal drugs for invasive candidiasis. This class is known as the echinocandins, which are showing to be more safe and effective and with fewer side effects than the other drugs; they can be used as an excellent therapeutic option, especially in cases of recent history of exposure to an azole, moderately severe to severe illness (i.e., hemodynamically unstable), and allergy or intolerance to azoles ${ }^{66-71}$. Although amphotericin $B$ remains a therapeutic option because of its broad spectrum and low cost, it produces side effects related to infusion and nephrotoxicity ${ }^{71-73}$. Thus, it is only used in case of microorganisms that are resistant to azoles and echinocandins and in patients who have an intolerance to these drugs, because their use may become more expensive and prolong hospital stay ${ }^{73}$.

\section{ACKNOWLEDGMENTS}

We thank all those who directly or indirectly contributed to the conclusion of this article, particularly the Jundiaí Medical College (Jundiai, SP) for giving us the space and facilities to complete this study.

\section{CONFLICT OF INTEREST}

The authors declare that there is no conflict of interest.

\section{FINANCIAL SUPPORT}

Conselho Nacional de Desenvolvimento Científico e Tecnológico $(\mathrm{CNPq})$.

\section{REFERENCES}

1. Ásmundsdóttir LR, Erlendsdóttir H, Haraldsson G, Guo H, Xu J, Gottfredsson M. Molecular Epidemiology of Candidemia: Evidence of Clusters of Smoldering Nosocomial Infections. Clin Inf Dis 2008; 47:e17-e24.

2. Kuzucu C, Durmaz R, Otlu B, Aktas E, Gulcan H, Cizmeci Z. Species distribution, antifungal susceptibility and clonal relatedness of Candida isolates from patients in neonatal and pediatric intensive care units at a medical center in Turkey. New Microbiol 2008; 31:401-408.

3. San Miguel LG, Cobo J, Otheo E, Sanchez-Sousa A, Abraira V, Moreno S. Secular trends of candidemia in a large tertiary-care hospital from 1988 to 2000: emergence of Candida parapsilosis. Infect Control Hosp Epidemiol $2005 ; 26: 548-552$.

4. Xavier PCN, Chang MR, Nunes MO, Palhares DB, Silva RA. Candidemia neonatal, em hospital público do Mato Grosso do Sul. Rev Soc Bras Med Trop 2008; .41:459-463

5. Manzoni P, Farina D, Galletto, P, Leonessa M, Priolo C, Arisio R, et al. Type and number of sites colonized by fungi and risk of progression to invasive fungal infection in preterm neonates in neonatal intensive care unit.J Perinat Med 2007; 35:220-226

6. Ozturk MA, Gunes T, Koklu E, Cetin N, Koc N. Oral nystatin prophylaxis to prevent invasive candidiasis in Neonatal Intensive Care Unit. Mycoses 2006; 49:484-492.

7. Levy I, Shalit I, Askenazi S, Klinger G, Sirota L, Linder N. Duration and outcome of persistent candidaemia in newborn infants. Mycoses 2006; 49:197-201.

8. Capriles CH, Mata-Essayag S, Azpiróz A, Ponente A, Magaldi S, Pérez C, et al. Neonatal candidiasis in Venezuela: Clinical and epidemiological aspects. Rev Latinoam Microbiol 2005; 47:11-20.

9. Roilides E, Farmaki E, Evdoridou J, Dotis J, Hatziioannidis E, Tsivitanidou M, et al. Neonatal candidiasis: analysis of epidemiology, drug susceptibility, and molecular typing of causative isolates. Eur J ClinMicrobiol Infect Dis 2004; 23:745-750

10. Perlroth J, Choi B, Spellberg B. Nosocomial fungal infections: epidemiology, diagnosis and treatment. Medical Micol 2007; 45:321-346.

11. Bliss JM, Basavegowda KP, Watson WJ, Sheikh AU, Ryan RM. Vertical and Horizontal Transmission of Candida albicans in Very Low Birth Weight Infants Using DNA Fingerprinting Techniques. Pediatric Inf Dis J 2008; 27:231-235.

12. Cook HA, Cimiotti JP, Della-Latta P, Saiman, L, Larson EL. Antimicriobial resistance patterns of colonizing flora on nurse's hands in the neonatal intensive care unit. Am J Infect Control 2007; 35: 231-236.

13. Lacaz CS, Porto E, Martins JEC, Heins-Vaccari EM, Melo NT. Tratado de Micologia Médica. São Paulo: Sarvier; 2002.

14. Kurtzman CP, Fell JW. The yeasts: a taxonomic study. New York: Elsevier Science; 1998.

15. Ruchel R, Uhlemann K, Boning B. Secretion of acid proteinases by different species of the genus Candida. Zbl Bakt Hyg I Abst Orig 1983; 255:237-248. 
16. Price MF, Wilkinson ID, Gentry LO. Plate methods for deteccion of phospholipase in Candida albicans. Sabouraudia 1982; 20:15-20.

17. Pfaller MA, Diekema DJ. Epidemiology of invasive candidiasis: a persistent public health problem. Clin Microbiol Rev 2007; 20:133-163.

18. Celebi S, Hacimustafaoglu M, Ozdemir O, Ozkaya G. Nosocomial candidaemia in children: results of a 9-year study. Mycoses 2008; 51:248-257.

19. Colombo AL, Guimarães T. Epidemiologia das infecções hematogênicas por Candida spp. Rev Soc Bras Med Trop 2003; 36:599-607.

20. St-Germain G, Laverdière M, Pelletier R, Bourgault AM, Libman M, Lemieux C, et al. Prevalence and antifungal susceptibility of 442 Candida isolates from blood and other normally sterile sites: results of a 2-year (1996 to 1998) Multicenter Surveillance Study in Quebec, Canada. J Clin Microbiol 2001; 39:949-953.

21. Borges RM, Soares LR, Brito CS, Brito DVD, Abdallah VOS, Gontijo PPF. Fatores de risco associados à colonização por Candida spp em neonatos internados em uma Unidade de Terapia Intensiva Neonatal brasileira. Rev Soc Bras Med Trop 2009; 42:431-435.

22. Colombo AL, Nucci M, Park BJ, Nouér SA, Arthington-Skaggs B, Matta DA, et al. Epidemiology of candidemia in Brazil: a Nationwide Sentinel Surveillance of candidemia in eleven medical centers. J Clin Microbiol 2006; 2816-2833.

23. Paula CR, Krebs VLJ, Auler ME, Ruiz LS, Matsumoto FE, Silva EH, et al. Nosocomial infection in newborns by Pichia anomala in a Brazilian intesive care unit. Medical Mycol 2006; 44:479-484.

24. Hinrichsen SL, Falcão E, Vilella TAS, Colombo AL, Nucci M, Moura L, et al. Candidemia em hospital terciário do nordeste do Brasil. Rev Soc Bras Med Trop 2008; 41:394-398.

25. Chen YC, Chang SC, Sun CC, Yang LS, Hsieh WC, Luh KT. Secular trends in the epidemiology of nosocomial fungal infections at a teaching hospital in Taiwan, 1981 to 1993. Inf Control Hosp Epidemiol 1997; 18:369-375.

26. Beck-Sague C, Jarvis WR. Secular trends in the epidemiology of nosocomial fungal infections in the United States, 1980-1990: National Nosocomial Infections Surveillance System. J Infect Dis 1993; 167:1247-1251.

27. Tamura NK, Negri MFN, Bonassoli LA, Svidzinski TIE. Fatores de virulência de Candida spp. isoladas de cateteres venosos e mãos de servidores hospitalares. Rev Soc Bras Med Trop 2007; 40:91-93.

28. Pfaller MA. Nosocomial candidiasis: emerging species, reservoirs, and modes of transmission. Clin Inf Dis 1996; 22:89-94.

29. Wenzel RP. Nosocomial candidemia: risk factors and attributable mortality. Clin Inf Dis 1995; 20: 1531-1534.

30. Donelli G. Vascular catheter - related infection and sepsis. Surg infect (Larchmt) 2006; 7:25-27.

31. Sobel JD. The Emergence of non-albicans Candida species as causes of invasive candidiasis and Candidemia. Curr Infect Dis 2006; 8:427-433.

32. Chang MR, Carvalho NCP, Oliveira ALL, Moncada PMF, Moraes BA, Asensi MD, et al. Surveillance of pediatric infections in a teaching hospital in Mato Grosso do Sul, Brazil. Braz J Infect Dis 2003; 7:149-160.

33. Sandven P. Epidemiology of Candidemia. Rev Iberoam Micol 2000; 17:73-81.

34. Ruiz LS, Sugizaki MF, Montelli AC, Matsumoto FE, Pires MFC, Silvia BCM, et al. Fungemia by yeasts in Brazil: I and phenotypic study of strain isolated at the public Hospital, Botucatu, São Paulo. J Micol Medicale 2005, 15:13-21.

35. Medrano DJ, Brilhante RS, Cordeiro RA, Rocha MF, Rabenhorst SH, Sidrim JJ. Candidemia in a Brazilian hospital: the importance of Candida parapsilosis. Rev Inst Med Trop São Paulo 2006; 48: 17-20.

36. Colombo AL. Epidemiology and treatment of hematogenous candidiasis: a Brazilian perspective. Braz J Infect Dis 2000; 4:113-118.

37. Silva EH, Ruiz LS, Matsumoto FE, Auler ME, Giudice MC, Moreira D, et al. Candiduria in a public hospital of São Paulo (1999-2004): characteristics of the yeast isolates. Rev Inst Med Trop São Paulo 2007; 49:349-353.

38. Matsumoto FE, Dias AL, Melhem MS, Szeszs MW, Auler ME, Ruiz LS, et al. Antifungal suscepitibily of bloodstream yeasts isolated at a public children's hospital Brazil: comparison of the Etest and the AFST-EUCAST microdilution method. Canadian J Microbiol 2007; 53:1300-1306.

39. Godoy P, Tiraboschi IN, Severo LC, Bustamante B, Calvo B, Almeida LP, et al. Species distribution and antifungal susceptibility profile of Candida spp. bloodstream isolates from Latin American hospitals. Mem Inst Oswaldo Cruz 2003; 98:401-405.
40. Cano MV, Perz JF, Craig AS, Liu M, Lyon GM, Brandt ME, et al. Candidemia in pediatric outpatients receiving home total parenteral nutrition. Med Mycol $2005 ; 43: 219-225$.

41. Matsumoto FE, Gandra RF, Ruiz LS, Auler ME, Marques SA, Gambale W, et al. Yeasts isolated from blood and catheter in children from a public hospital of São Paulo, Brazil. Mycopathologia 2002; 154: 63-69.

42. Matta D, Machado A, Azevedo A, Almeida L, Kusano E, Travassos N, et al. Antifungal suscepitibility of 1000 Candida bloosstream isolated to 5 antifungal drugs: results of a multicenter study coducted in São Paulo, Brazil, 1995-2003. Diagn Microbiol Infect Dis 2007; 57:399-404.

43. Colombo AL, Nucci M, Salomão R, Branchini ML, Derossi A, Richtmann R, et al. High rate of non-albicans candidemia in Brazilian tertiary care hospitals. Diagn Microbiol Infect Dis 1999; 34:281-286.

44. Colombo AL, Perfect J, DiNubile M, Bartizal K, Motyl M, Hicks P, et al. Global distribution and outcomes for Candida species causing invasive candidiasis: results from an international randomized double-blind study of caspofungin versus amphotericin B for the treatment of invasive candidiasis. Euro J Clin Microbiol Inf Dis 2003; 22:470-474.

45. Costa SF, Marinho I, Araújo EA, Manrique AE, Medeiros EAS, Levin AS. Nosocomial fungemia: a 2-year prospective study. J Hosp Inf 2000; 45:69-72.

46. Goldani LZ, Mario PS. Candida tropicalis fungemia in a tertiary care hospital. $\mathrm{J}$ Inf 2003; 46:150-160.

47. Antunes AGV, Pasqualotto AC, Diaz MC, D’Azevedo PA, Severo LC. Candidemia in a Brazilian Tertiary care Hospital: species distribution and antifungal susceptibility patterns. Rev Inst Med Trop 2003; 46:239-241.

48. Fidel PL, Vazquez JA, Sobel JD. Candida glabrata: review of epidemiology, pathogenesis, and clinical disease with comparison to C. albicans. Clin Microbiol Rev 1999; 12:80-96.

49. Pfaller MA, Jones RN, Doern GV, Sader HS, Hollis RJ, Messer SA, et al. International surveillance of bloodstream infections due to Candida species: frequency of occurrence and antifungal susceptibilities of isolates collected in 1997 in the United States, Canada, and South America for the SENTRY program. J Clin Microbiol 1998; 36:1886-1889.

50. Santos IBC, Oliveira NMC, Casimiro GS, Xavier DE, Santos IB, Lima EO, et al. Freqüência de leveduras isoladas em mäos de profissionais de saúde em um hospital público de Joäo Pessoa - PB. Revista Bras Anal Clín 2002; 34:155 - 159.

51. Martins-Diniz JN, Silva RAM, Miranda ET, Mendes-Giannini MJS. Monitoramento de fungos anemófilos e de leveduras em unidade hospitalar. Rev Saude Publica 2005; 39:398-405.

52. Tamura NK, Negri MFN, Bonassoli LA, Svidzinski TIE. Fatores de virulência de Candida spp isoladas de cateteres venosos e mãos de servidores hospitalares. Rev Soc Bras Med Trop 2007; 40:91-93.

53. Mohan V, Ballal M. Proteinase and phospholipase activity as virulence factors in Candida species isolated from blood. Rev Iberoam Micol 2008; 25:208-210.

54. Strausbaugh LJ, Sewell DL, Ward TT, Pfaller MA, Tjoelker RC, Heitzman T. High frequency of yeast carriage on hands of hospital personnel.J Clin Microbiol $1994 ; 32: 2299-2300$.

55. Hota B. Contamination, disinfection, and cross-colonization: are the hospital surface reservoirs for nosocomial infection? Clin Inf Dis 2004; 39:1182-1189.

56. Alvarez-Lerma F, Palomar M, Léon C, Olaechea P, Cerda E, Bermejo B. Infection in intensive care units for fungal colonizations. Med Clin 2003; 121:161-166.

57. Trick WE, Vernon MO, Hayes RA, Nathan C, Rice TW, Peterson BJ, et al. Impact of ring wearing on hand contamination and comparison of hand hygiene agents in a hospital. Clin Infect Dis 2003; 36:1383-1390.

58. Gulay Z, Ergon C, Ozkutuk UM, Yucesoy M, Bicmen M. Molecular epidemic surveillance and sensibility of antifungal agents of $C$. albicans isolated in intensive care units. Mikrobiyol Bul 2002; 36:309-316.

59. Gokce G, Cerikcioglu N, Yagci A. Acid proteinase, phospholipase, and biofilm production of Candida species isolated from blood cultures. Mycopathologia 2007; 164:265-269.

60. Silva JO, Ferreira JC, Candido RC. Atividade enzimática, produção de slime e sensibilidade a antifúngico de Candida sp. Rev SocBras Med Trop 2007; 40:354-355.

61. Yenioehirli G, Bulut Y, Tunçoglu E. Phospholipase, proteinase and hemolytic activities of Candida albicans isolates obtained from clinical specimens. Mikrobiyol Bul 2010; 44:71-77. 
62. Mohan V, Ballal M. Proteinase and phospholipase activity as virulence factors in Candida species isolated from blood. Rev Iberoam Micol 2008; 25:208-210.

63. Oksuz S, Sahin I, Yildirim M, Gulcan A, Yavuz T, Kaya D, et al. Phospholipase and Proteinase activities in different Candida species isolated from anatomically distinct sites of healthy adults. Jpn J Infect Dis 2007; 60:280-283.

64. Matta VLR, Melhem MSC, Colombo AL, Moretti ML, Rodero L, Almeida GMD, et al. Antifungal drug susceptibility profile of Pichia anomala isolates from patients presenting with nosocomial fungemia. Antimicrobial Agents Chemother 2007; 51:1573-1576.

65. Pfaller MA, Diekema DJ, Mendez M, Kibbler C, Erzsebet P, Chang SC, et al. Candida guillermondii, an opportunistic fungal pathogen with decreased susceptibility to fluconazole: geographic and temporal trends from the ARTEMIS DISK antifungal surveillance program. J Clin Microbiol 2006; 44:3551-3556.

66. Frattarelli DA, Reed MD, Giacoia G, Aranda JV. Antifungals in systemic neonatal candidiasis. Drugs 2004; 64:949-968.

67. Moreira MEL. Controvérsias a respeito da sepse fungica no pré-termo extremo: profilaxia e esquemas terapêuticos. J Pediatria 2005; 81:S52-S58.

68. Bassetti M, Righi E, Tumbarello M, Di Biagio A, Rosso R, Viscoli C. Candida infections in the intensive care unit: epidemiology, risk factors and therapeutic strategies. Expert Rev Anti Infect Ther 2006; 4:875-885.

69. Schelenz S. Management of candidiasis in the intensive care unit. J Antimicrobial Chemother 2008; 61:31-34.

70. Pappas PG, Ostrosky-Zeichner L. Invasive candidiasis in the intensive care unit. Crit Care Med 2006; 34:857-863.

71. Pappas PG, Kauffman CA, Andes D, Benjamin DK, Calandra TF, Edwards JE, et al. Clinical Practice Guidelines for the Management of Candidiasis 2009 Update by the Infectious Diseases Society of America. Clin Infect Dis 2009; 41:503-535.

72. Pappas PG, RexJH, Sobel JD, Filler SG, Dismukes WE, Walsh TJ, et al. Guidelines for treatment of candidiasis. Clin Infect Dis 2004; 38:161-189.

73. Baran Jr J, Muckatira B, Khatib R. Candidemia before and during the fluconazole era: prevalence, type of species and approach to treatment in a tertiary care community hospital. Scand J Infec Dis 2001; 33:137-139. 